\title{
The Suffocating Embrace of Landscape and the Picturesque Conditioning of Ecology
}

\section{Citation}

Ellison, Aaron M. 2013. The suffocating embrace of landscape and the picturesque conditioning of ecology. Landscape Journal 32, no. 1: 79-94.

\section{Published Version}

doi:10.3368/lj.32.1.79

\section{Permanent link}

http://nrs.harvard.edu/urn-3:HUL.InstRepos:11315411

\section{Terms of Use}

This article was downloaded from Harvard University's DASH repository, and is made available under the terms and conditions applicable to Other Posted Material, as set forth at http:// nrs.harvard.edu/urn-3:HUL.InstRepos:dash.current.terms-of-use\#LAA

\section{Share Your Story}

The Harvard community has made this article openly available.

Please share how this access benefits you. Submit a story.

\section{Accessibility}


1 The suffocating embrace of landscape and the picturesque conditioning of ecology

2 Aaron M. Ellison 
4 ABSTRACT What are natural landscapes? Are they "out there," separate from people, or are

5 they creations of our own perception? An exploration of artistic visions of landscape on the one

6 hand and the development of ecology as a self-conscious science on the other suggests that for

7 nearly 150 years ecology has been conditioned by romantic, picturesque portrayals of landscape.

8 Landscape (as landscab) originally implied people living within and shaping a capricious nature,

9 but rapidly evolved to landtskip: natural scenery reflecting a balance of nature viewed from the

10 outside. Despite repeated scientific demonstrations of the lack of ecological balance at any time

11 now or in the past, ecologists (and most other people) persist in clinging to a romantic

12 conception of landscape with nature in balance. An explicit analogy between Fernand Léger's

131959 lithograph La Ville - Le Viaduc and an old-growth Douglas fir/Western red cedar forest

14 suggests that Modernist or Postmodernist visions of landscape may be more realistic visual

15 representations of nature. To reframe and reconfigure ecology and environmental stewardship to

16 better reflect current understanding of how nature - including people - "works," contemporary

17 landscape artists must engage with ecologists, environmental scientists, landscape architects, and

18 the broader public to redefine the nature of nature.

19

20 KEYWORDS Ecology, landscape, landscape art, Modernism, Postmodernism, old-growth

21 forests, sublime 
22 "[t]he most lovely and perfect parts of nature may be brought together, and combined in a 23 whole, that shall surpass in beauty and effect any picture painted from a single point of view." -Thomas Cole (letter to Robert Gilmor, 25 December 1826; fide Hood 1969, 42)

26 "In the Grand Canyon, Arizona has a natural wonder which is in kind absolutely unparalleled

27 throughout the rest of the world. I want to ask you to keep this great wonder of nature as it now

28 is. ... I hope you will not have a building of any kind, not a summer cottage, a hotel, or anything

29 else, to mar the wonderful grandeur, the sublimity, the great loneliness and beauty of the canyon.

30 Leave it as it is. You cannot improve on it. The ages have been at work on it, and man can only

31 mar it."

34 "That there is a balance of nature is one of the most deep-seated assumptions about the natural 35 world, the world we know on planet Earth." 
38 What are "natural landscapes?" Landscape artists capture them on canvas, landscape architects

39 plan, design and build them, and landscape ecologists study and interpret them. Each of these

40 groups tends to work independently, but there are strong intellectual linkages among them (e.g.,

41 Cronon 1995, Nassauer 1995, Gobster et al. 2007). In general, these linkages have been seen as

42 directional, moving from the "natural world" that is catalogued and quantified by scientists into

43 our consciousness through human perception and design and artistic interpretation (McHarg

44 1969, Meyer 2000). For example, Kelsey (2008) suggested that ecology provides ways to think

45 about how physical processes produce landscapes, which artists and landscape architects

46 subsequently reshape. Cosgrove (2008) went further, looking to human constructs, especially

47 maps, to remove people (and landscapes) from the "suffocating embrace of ecology" and to

48 provide them with a more concrete place in the world. The endpoint of this process is that the

49 picturesque caricatures of nature that emerge in designed landscapes or landscape art are seen to

50 represent nature itself (Cronon 1995, Nassauer 1995, Kelsch 2000), yet at the same time

51 designed landscapes require constant maintenance to ensure their persistence (e.g., Downing

52 1841, Meyer 2000, Nadenicek and Hastings 2000, Spirn 2000, Jordan and Lubick 2011).

53 Recognition of these caricatures and the desire to reduce subsequent maintenance can lead to

54 calls for built landscapes to better reflect nature, natural processes, or other (but rarely-defined)

55 ecological qualities (McHarg 1969, Nassauer 1995, Cook 2000, Meyer 2000). But can we

56 actually define nature or ecological quality independently of our interpretation of it?

57 Ecologists — scientists who study nature and natural processes — are equally subject to

58 cultural norms and to being conditioned by long exposure to cultural and picturesque

59 conventions. In this essay, I explore the reciprocity between, on the one hand, romantic ideas and

60 artistic visions of landscape, and on the other, the development of ecology as a self-conscious 
61 science (Kingsland 2008) and advocate for the environment (Strong 2008). ${ }^{1}$ My intent here is to

62 hold Cosgrove's (2008) "suffocating embrace of ecology" up to an ecological mirror and to show

63 how landscape art can be a lens through which we can view the history and development of

64 ecology from its beginnings as a scientific discipline in the mid-19 ${ }^{\text {th }}$ century (see Egerton 2012

65 for its ancestral antecedents), its transformation into environmentalism beginning in the 1920s,

66 and its emerging role in $21^{\text {st }}$-century planetary stewardship (Power and Chapin 2010). In short, I

67 assert that ecology has for nearly 150 years been suffocated by a romantic notion of landscape

68 and an artistic portrayal of nature in balance (Kricher 2009); as Cronon (1995) pointed out, we

69 (ecologists) may in fact be studying the wrong nature. My focus here is on the intersection

70 between landscape art (especially its portrayal of "natural landscapes" in North America) and

71 ecological science; ecologists, even landscape ecologists, rarely study architect-designed

72 landscapes, and most ecologists would consider them to be pale imitations of "nature."

73 This essay consists of four parts. ${ }^{2}$ First, I briefly trace the origin of "landscape" and its

74 reification in the broad, public consciousness through $19^{\text {th }}$-century landscape painting and

75 dissemination of an affordable aesthetic for landscape architecture. Second, I illustrate with a

76 series of examples of how repeated scientific demonstrations of the lack of natural balance at any

77 time now or in the past have been subsequently subsumed by new paradigms of balance that

78 reflect a romantic conception of landscape. Third, I suggest that Modernist and Postmodernist

79 visions of landscape present, respectively, a template or framework for, and more realistic visual

80 representations of, nature, and indeed already may provide a model for a contemporary sublime

81 (cf. Volk 2008). ${ }^{3}$ An explicit analogy between Fernand Léger's 1959 lithograph La Ville - Le

82 Viaduc with an old-growth Douglas fir/Western red cedar forest illustrates this suggestion. In

83 these second and third sections, I deliberately reverse the standard model of linkages from 
84 ecology to landscape art and architecture; instead I focus on how ecologists and ecological

85 science have been conditioned by, and at the same time have resisted, broader cultural trends.

86 Finally, I conclude with a call for contemporary landscape artists and landscape architects to

87 fully engage with scientists (especially ecologists and environmental scientists) and the broader

88 public to redefine the nature of nature ( $c f$. Bernal 1937, Cronon 1995, Nassauer 1995, Buijs et al.

89 2011). Such broad engagement is commonplace among artists, architects, and the general public

90 (Joselit 2013) but occurs much less frequently between scientists and non-scientists. In

91 particular, the ongoing renaissance of landscape art and architecture can and must have a

92 transformative effect on ecologists if we are to reframe and reconfigure ecology and

93 environmental stewardship to better reflect current understanding of how nature-including

94 people - "works." Neither landscape art and landscape design nor ecological science should be

95 ceded to romantic notions of nature ${ }^{4}$ - nature out there, without people, and without the constant

96 buffeting of chronic disturbances and chaotic dynamics that are ever present in the world.

97

98 LANDSCAPE ART IN CONTEMPORARY CONSCIOUSNESS

99 Landscape art is one of the most enduring art forms. Although some art historians have asserted

100 that American landscape art reached its pinnacle with $19^{\text {th }}$-century romanticism and ceased being

101 an active concern of serious artists by the 1850s (e.g., Cosgrove 1998), others have recognized

102 the continuing influence of artists of the Hudson River School, such as Thomas Cole and

103 Frederic Edwin Church, not only on both Modernist and Postmodernist artistic visions of

104 landscape but also on the aspirations of American politicians and the general populace

105 (Markonish 2008, Schuyler 2012). Exhibitions of landscape paintings regularly draw large

106 crowds. ${ }^{5}$ Reproductions of classical landscape paintings and new landscape paintings executed in 
107 realist modes enjoy brisk sales and recall the rock star-like qualities attributed to Church,

108 Thomas Moran, and other Hudson River School painters (Hicks 2010). ${ }^{6}$

109 In their heyday, the Hudson River School painters reflected Teddy Roosevelt's

110 epigraphic vision of the Grand Canyon: nature cannot be improved and is best left alone without

111 people in it, except as observers and recorders. The continued impact of the Hudson River

112 School cannot be underestimated (Schuyler 2012) and reflects not only its resonance with deep-

113 seated assumptions about how we think nature works (Kricher 2009, Botkin 2012), but perhaps

114 more importantly, the widespread dissemination in affordable formats of plans and designs for

115 implementing Hudson River-type landscapes at home (e.g., Downing 1841, 1842, 1861). ${ }^{7}$

116 The conscious emplacement of people outside of nature and landscape is commonly

117 referred to as environmental (or ecological) consciousness (Jordan and Lubick 2011): the notion

118 of landscape as Badland - landscape in decline around us, in peril we have caused, and pain we

119 are inflicting (Whelan 2008) — recapitulates Denis Cosgrove's reference to (post-Hudson River

120 School) landscape art as being enmeshed in "the suffocating embrace of ecology" (Fig. 1). The

121 distinct place of people outside of nature also is reflected in how landscape is (and was) defined

122 and generally understood. Originally, landscab encompassed a view of people being within and

123 shaping the landscape. The land in the German landschaft, the Danish landschap, and the Old

124 English landscape meant both a place itself along with the people of the place; the suffixes or

125 combination forms -skab, -schaft, and -ship meant association or partnerships, and were

126 themselves derived from skabe and schaffen - "to shape" (Spirn 2008). But by the $17^{\text {th }}$ century,

127 Dutch painters were referring to landscape as landtskip, which represents natural scenery that

128 people view from without (OED 2011). This view of landscape as landtskip was embodied by

129 Hudson River School and persists to the present day. 
131 unprecedented and rapid changes in the $19^{\text {th }}$ and early $20^{\text {th }}$ Centuries attendant to the opening,

132 exploration, and closing of the western frontier in North America, and worldwide

133 industrialization and urbanization provided different visions of the nature of landscape. Many

134 people, including policy- and decision-makers, viewed the land as a source from which "natural

135 resources" could be extracted, as a place to cultivate crops or graze animals, or simply as a pretty

136 backdrop for human activities, including a nascent industry in nature tourism (Brown 1995).

137 Landscape artists responded to these visions; George Inness illustrated changes to the landscape

138 associated with industrialization; Louis Prang used new the new technology of

139 chromolithography to distribute widely industrial images (Mancini 2005); and John Frederick

140 Kensett oriented his work towards scenic tourism (Bedell 2001), To the Hudson River School

141 painters, however, the vision of a sublime nature provided scenery and lessons for people

142 nostalgic for a supposed prelapsarian era, and simultaneously trying either to coexist with it in its

143 current, rapidly changing form or restore it to its previous grandeur (e.g., Mancini 2005, Jordan

144 and Lubick 2011).

145

\section{LANDSCAPE, ECOLOGY, AND THE BALANCE OF NATURE}

147 By the late $19^{\text {th }}$ century, the western boundaries of the United States were settled, the frontier 148 was closed, national parks were being established as peaceful refuges in nature for urban 149 dwellers, and ecology was emerging as a science (Kingsland 2008, Jordan and Lubick 2011).

150 The idea of nature being somewhere else, being a refuge, and being somehow different from the 151 chaos in which people lived was encapsulated in ecological science as the "balance of nature." 
152 The idea of nature in balance also entered ecological science through early $19^{\text {th }}$-century

153 theoretical models of physical systems based on idealized assumptions (Botkin 2012, 31).

154 Ecology as a scientific discipline originated in the mid-1800s (Haeckel 1866), during the

155 second generation of Hudson River School painters and contemporaneous with the establishment

156 of the U.S. National Park System, the first in the world. Ironically, one of the main arguments for

157 the protection (in 1872) of Yellowstone National Park was to prevent it from becoming another

158 Niagara Falls, which already had been heavily commercialized by the time it was portrayed as

159 the ultimate in the sublime in the paintings of Cole and Church. Within 20 years of the

160 identification of ecology as a distinct discpline, scientists studying ecological processes were

161 already remarking that "[p]erhaps no phenomenon of life in such a situation is more remarkable

162 than the steady balance of organic nature" (Forbes 1887, 86) and the underlying causes of this

163 remarkable balance became a defining feature of ecological research. By the early 1900s,

164 ecology had its own professional scientific societies, meetings, and professional journals; the

165 British Ecological Society was founded in 1913, and the Ecological Society of America was

166 founded in 1915 (Macintosh 1985, Kingsland 2008). The broader cultural context of the founders

167 of the discipline could be found in fin de siècle America, where the "landscape" already had been

168 reified in paintings by Bierstadt, Church, and Moran (Bedell 2001), in state and national parks, in

169 England's formal gardens and America's country estates and "cottages" (Schuyler 2012), and in

170 contemporary poetry that reflected Cole's epigraphic vision of a landscape painting that

171 surpasses the beauty of any real landscape (Kroeber 1975, Heringman 2004).

172 Early ecologists implicitly assimilated these picturesque ideals. Foundational research

173 focused on the structure of vegetation and asked whether groups of different plant species

174 formed "formations" or "superorganisms" in balance with regional climate and geology 
175 (Clements 1916), or whether these same assemblages of species were simply the results of

176 random events: lucky seeds germinating in good places that went on to become adult plants

177 winning the competition race for space over later arrivals (Gleason 1926). The idea of

178 climatically-determined, balanced plant communities and their associated animals prevailed.

179 By the 1930s, while Modernism was flowering in art and architecture (Wood 2003),

180 ecologists, recapitulating the biblical telling of the expulsion from Eden, were mourning the loss

181 of the balance of nature at the hands of man (Smith 1932, 649-650):

182

183

"A hundred years ago, the great plains [of Kansas] were still largely in their primeval state. A balance of biological life or organic groups had been set up through the ages and this balance probably then was but little disturbed. ... Man, that great disturber of natural balances, came to this area, sometimes called the 'Great American Desert,' to establish homes and to wrest a living out of this virgin soil. ... These profound changes have been accompanied by a recognizable series of biological phenomena which might be expected to follow, upsetting this ancient harmony among living things."

192 These ideas undergirded federal legislation to protect and restore wildlife (the 1937 Pittman193 Robertson Wildlife Restoration Act, still the major piece of legislation financing wildlife 194 management in the United States; Organ 2012), and permeate the theory and practice of modern 195 restoration ecology (Jordan and Lubick 2011, Botkin 2012). Similar sentiments can be found in 196 the post-World War II writings of Aldo Leopold, Rachel Carson, and Eugene Odum, among 197 many others, and were commonplace in ecological textbooks by the 1950s (Odum 1969). These 
198 ideas were so broadly representative of the paradigms in which scientists worked that when

199 Nobel Laureate Norman Borlaug published a lecture on the myth of the balance of nature,

200 (Borlaug 1972), the editors of BioScience, the international journal in which the essay was

201 published, felt it incumbent to preface his article with an excerpt from their editorial policy

202 statement: "We do not propose to avoid controversy because we believe that differing viewpoints

203 should be heard, but the subject must have biological relevance. We will, of course, publish

204 expressions of opposing opinions.” Ultimately, the Clementsian concept of ecosystem as a

205 balanced superorganism gave rise to Lovelock's Gaia Hypothesis, in which “stable optimal

206 conditions for the [entire] biosphere have prevailed for thousands of millions of years"

207 (Lovelock and Margulis 1974, 93; see also Lovelock 1965).

208 The balance of nature describes a condition in which populations of organisms either are

209 unchanging through time or are regulated within finite, generally narrow bounds or predictable

210 cycles. Ecologists from the 1920s through the early 1970s continually argued from conflicting

211 observations, experimental data, and mathematical models whether or not populations were

212 regulated internally (population growth slows down as densities increase) or externally

213 (unpredictable changes in weather or climate prevent populations from exceeding the carrying

214 capacity of their environment). Counter-intuitively, realistic models of interacting organisms

215 rarely yielded stable or balanced systems (May 1972), but even the creator of these models

216 retreated from the brink of ecological chaos, asserting that contingent generalizations about the

217 structure of nature are nonetheless possible (May 1986).

218 At the same time, the discovery of the ozone hole, the increasing pace of climate change,

219 and the concurrent disintegration of natural systems suggested either a world out of balance or-

220 at its most extreme-a world that had never been in balance (Wu and Loucks 1995, Cook 2000, 
221 Botkin 2012). Postmodernist visions of landscapes expressed this perspective - examples include 222 Robert Smithson's (and others') Earthworks (Kastner and Wallis 1998), Andy Goldsworthy's

223 photographs and vanishing sculptures, and Paul Jacobsen's The Final Record of the Last Moment 224 in History (Fig. 1) - but like ecology and ecologists, these and other works hearkened to a better

225 time when nature was still in balance. ${ }^{8}$ In commenting on his own work, and in response to an 226 interviewer's question about how he balances beauty in the face of a horrible future, Jacobsen 227 recalled a moment of clarity when he viewed the 2007 Guggenheim Museum exhibition Arcadia 228 and Anarchy (Markonish 2008, 58):

229

"The work [in the exhibition] seemed to begin with a lot of social pieces about the workers and resistance but then changed to paintings of idyllic landscapes. It clarified for me that the painter who hopes to change things might as well retreat to the woods and paint mystical scenes of naked women."

As a result, he views The Final Record of the Last Moment in History (Fig. 1) as the last spectacle, in a future with no place for this or any of his other paintings. ${ }^{9}$ Yet the balance of nature continued to lurk even in an unbalanced ecology. What was once the balance of nature became a "metastable dynamic equilibrium" (Wu and Loucks 1995, 239 460):

"Nature is not in constant balance, and patchiness is ubiquitous. The metastability suggested by hierarchical patch dynamics differs theoretically and structurally from the static stability implied by both the balance of nature and the 
252 In other words, we were simply looking for balance at the wrong scales in time and space. ${ }^{10}$ And 253 now, nearly two decades on, we again have come full circle. Despite occasional resurgences of 254 non-equilibrium thought (e.g., Cook 2000, Botkin 2012), the balance of nature continues to be a 255 persistent metaphor guiding how scientists organize their research and how non-scientists view the world (e.g., Nicholls 2009). For example, a recent survey illustrates that undergraduate students — both science and non-science majors — and the broader educated populace believe that "the balance of nature" is a valid descriptor of real ecological systems (Zimmerman and Cuddington 2007). The widespread and rapid death of oaks on the Massachusetts island of Martha's Vineyard led a resident to state that the death of the trees was "a sign we are out of balance. If a person is sick, they are open to diseases. It's the same with the planet and the trees" (Struck 2010). Similar metaphors of equilibrium and balance guide research and practice in disciplines from molecular biology to geomorphology to law (e.g., Nivala 1988, Bracken and Wainwright 2006, Martínez-Frías 2008). ${ }^{11}$ 


\section{A MODERNIST VISION OF LANDSCAPE: LÉGER'S LA VILLE - LE VIADUC}

267 Worldwide, the popular conception of landscape art reflects the Hudson River School and its

268 descendants (Schuyler 2012). Nonetheless, many landscape artists, especially European ones,

269 never shied away from depicting nature as cruel, capricious, or unpredictably unbalanced.

270 Friedrich's The Monk by the Sea (Fig. 2) shows viewers a boundless and empty scene that

271 Andrews (1999) considered horrifying and lacking any reassurance about the comfort or

272 equanimity of nature. Turner's Snow Storm (Fig. 3) is a frighteningly accurate portrayal of a

273 person lost at sea in a squall. Critics panned it when it was exhibited, and Turner himself said

274 that while he "wished to show what such a scene was like ... no one had any business to like the

275 picture" (quoted in Andrews 1999, 177).

276 As landscape artists working in plein air moved from realistic, yet idealized, portrayals of

277 nature to a more nuanced understanding of underlying natural processes, the paintings

278 themselves became more abstract, then more jarring. Simultaneously, the scenes portrayed

279 shifted from rural (e.g., the impressionist landscapes of Cézanne and Monet) to urban (e.g., the

280 abstract cityscapes of Mondrian and Léger; see below), paralleling the modern shift in human

281 settlement patterns from primarily rural to primarily urban that continues to the present day. But

282 ecology, ecologists, and environmentalists remained locked in the suffocating embrace of

283 romantic era landscape and continue to resist this shift. For example, the journal Urban Ecology

284 lasted only a decade (1975-1986) and was renamed and refocused as Landscape and Urban

285 Planning thereafter. The U.S. Long Term Ecological Research program began in 1986 focused

286 on "natural" ecosystems and only established its two urban sites in 1998. Among scientists, this

287 disconnection from the city and the "modern" is not limited to ecologists; the October 21, 2010

288 issue of the international scientific journal Nature used its cover, editorial page, and a special 
section to remind us that scientists continue to ignore the needs of cities despite the fact that

290 more than half the world's people live in cities and virtually all the world's universities and

291 researchers are in cities.

292 Two paintings clearly illustrate this shift in perspective: Piet Mondrian's Broadway

293 Boogie Woogie (Fig. 4) and Fernand Léger's La Ville - Le Viaduc (Fig. 5). The jazz-influenced

294 Broadway Boogie Woogie is rhythmic and chromatically balanced, yet profoundly disturbing.

295 Mondrian himself referred to it as his own "destruction of natural appearance; and construction

296 through continuous opposition of pure means - dynamic rhythm." ${ }^{\prime 2}$ In lectures and workshops I

297 have given on this topic at Harvard, Oregon State, Florida State, and Boston Universities,

298 participants_-including undergraduates, graduate students, and faculty in studio art, ecology,

299 forestry, computer science, and engineering — were asked to provide immediate emotional

300 responses to these two paintings. Artists recognized both paintings but ecologists did not

301 recognize either of them. Artists described Broadway Boogie Woogie as wild, playful, or jazzy,

302 whereas ecologists described it as an abstract, patchwork, maze-like city map or a video game

303 (references to Pac-Man are common), and definitely as "not nature" (or "natural"). ${ }^{13}$

304 The cartoon-like, modernist Le Viaduc portrays essential elements of the cityscape: an

305 aqueduct in the lower right; a construction crane in the upper middle; a chimney; and a building.

306 Like Mondrian, Léger viewed his painting The City (1919) — the precursor to the La Ville series

307 of lithographs — as illustrating "dynamic divisionism" with jazz-like rhythms that span the

308 painting (Lanchner 2010, 16). Art historians have interpreted Léger's work as illustrating the

309 "dissonant contrasts, pace, and fragmentary quality of life that he saw and relished in the

310 increasingly industrialized new century" (Lanchner 2010, 9), and the artists with whom I have

311 discussed Le Viaduc call it an illustration of a quirky, happy, playful city. In striking contrast, the 
312 smiling, red-eyed, cut-off clown prompts ecologists to whom I have shown Le Viaduc to view

313 the entire cityscape as complex, detached, creepy, and even sinister; an urban metastasis that

314 keeps on coming and growing (and thus overtaking nature). In striking contrast, artists'

315 acceptance of this reconfiguration and re-conceptualization of landscape belies the notion that

316 they are suffocating in an embrace of ecology, but ecologists' continued resistance to a view of

317 landscape as capricious, destructive, or out of balance reflects not nature itself, but the embrace

318 of a landscape we want to see, and what sorts of questions we ask of it. In studying a "nature"

319 whose definition is conditioned by a societal consensus of nature as harmonious other

320 (Nadenicek and Hastings 2000), ecologists continue to struggle with these, and other, conflicting

321 views of nature in professional practice (Jordan and Lubick 2011, Botkin 2012), and in language

322 and metaphors used to describe nature and people's place in it (Larson 2011).

\section{THE POSTMODERN LANDSCAPE: OLD-GROWTH FORESTS}

325 Like Léger's Le Viaduc, old-growth forests illustrate ecologists' contradictions. Ancient

326 towering trees with silent, moss-covered limbs and thick soil that muffle a walker's steps

327 epitomize nature's balance. Old-growth forests are routinely compared with cathedrals (e.g.,

328 Cathedral Pines, an old-growth stand of white pine trees in Cornwall, Connecticut owned by The

329 Nature Conservancy, and the Cathedral Grove of old-growth kauri trees in New Zealand's

330 Waipoua forest preserve), and individual trees are referred to as the Mother or Father of the

331 Forest (the actual names given by the park service to two trees on the Redwood Loop trail in Big

332 Basin Redwoods State Park, Santa Cruz, California; likewise the second-largest kauri tree in

333 New Zealand is The Father of the Forest [Maori: Te Matua Ngahere]). Like cathedrals and

334 parents, these forests not only are perceived as timeless but are protected in perpetuity: majestic 
335 groves of sequoias were among the first areas set aside in national parks (1890), state parks to

336 protect the redwoods date to the 1920s, and Redwood National Park was established in 1968.

337 Yet, a detailed examination of old-growth Douglas Fir forests in the Central Cascade Range of

338 Oregon suggests that the old-growth forest we cherish may be nothing more than a historical

339 accident driven by episodes of intense forest fires (Tepley 2010). For example, more than 100

340 stands of old-growth established in a very short time-window in the 1500 s, soon after a series of

341 unusually large fires swept through the region (Fig. 6). What caused these intense fires then and

342 how often such intense periods of conflagration occur remain unclear, but there is no evidence

343 yet for their predictability or any balance between the forest and their environment (Colombaroli

344 and Gavin 2010). In fact, all of the data we have clearly indicate that old-growth forests are, at

345 least in forest time, ephemeral. This ephemeral uniqueness, not a timeless balance, is a much

346 better reason to cherish old-growth forests.

347 Yet even between fires, forests are in motion. As in disintegrating Earthworks, the earth

348 creeps, slumps, and flows down hillsides beneath the trees of the old-growth forest at Lookout

349 Creek in Oregon. These unstable conditions lead to episodic landslides; in between them, the

350 movement of soil, as much as 15 millimeters (more than $1 / 2$ an inch) per year, pulls fire-scarred

351 trees apart at the seams (Fig. 7). The current slip and creep of the soil has been going on for at

352 least 300 years at this site, perhaps coincident with the establishment of this Douglas fir/Western

353 red cedar old-growth forest (Swanson and Swanston 1977). Soils prone to such slippage

354 originated in volcanoes, and eruptions themselves occur episodically and unpredictably.

355 This forest mirrors, but situates, Le Viaduc (Fig. 8). Despite being on a steep south-facing

356 slope, the trees fall at every angle, sometimes landing on the ground, sometimes perched on each

357 other. The crazy quilt of split trees, fallen trees, shattered logs, and depressions recalling once 
358 flowing but now blocked streams induces vertigo. The roots of splitting trees are like rock-

359 climber's toes, grasping for an ephemeral perch, and an observer similarly grasps for a fixed

360 frame of reference, but finds none. At any scale - from the daily rhythms of growing and dying

361 plants to the eons of soil formation interspersed by volcanism, landslides, and germinating

362 trees - this is nature in all its unbalanced glory!

\section{RE-IMAGINING THE SUBLIME, RE-ENGAGING WITH THE WORLD}

365 The suffocating embrace of romantically-infused notions of landscape has cut humans off from

366 nature and from the world. ${ }^{14}$ When I ask "what is nature", ecologists and artists alike answer "the

367 world beyond my house", "the parts of the world beyond human control", or "the places I go to

368 get away from people and refresh my mental energies." Similarly, the second generation of

369 Hudson River School painters rarely featured humans in their landscapes. The ideal photographs

370 of landscape or nature almost never have people in the frame, and contemporary portrayers of

371 landscapes, including Earth artists and those represented in the 2008-2009 Badlands exhibition,

372 either recapture Thomas Cole's epigraphic vision of a perfect, unattainable world or a once-

373 balanced world now despoiled by humanity.

374 People are animals - not only metaphorically, but also literally. Like all animals, we are

375 born, we grow, we kill to eat, we reproduce, and we die. Like many animals, we change our

376 world (e.g., Jones, Lawton, and Shachak 1994, Ellison et al. 2005). Over millions of years, we

377 evolved from ape-like ancestors, which themselves evolved from other species. And like all

378 species, we will eventually go extinct, disappearing from this world but leaving traces behind-

379 fossils, middens, art - that will eventually decay into their component atoms that are reborn and

380 reused in new objects and new species. 
Evolution is a messy business. Like modern capitalism, evolution is a process of creative

382 destruction. Darwin described a struggle for existence between organisms and the world around

383 them, a struggle that includes not only the elements but other organisms. Modern evolutionary

384 ecologists measure changes in the frequency and type of genes, but the cause and the result is

385 ultimately the same: change is ceaseless and organisms are all constantly off-balance, just trying

386 to survive.

But an off-balance world is not a free-for-all where we can do anything we want and

388 damn the consequences. We humans think — but if thought is the firing of neurons, all animals

389 think — but we are different from all other animals because we are aware and self-conscious not

390 only of our actions but also of the consequences of our actions. With awareness comes

391 responsibility - responsibility not only for ourselves but for all our fellow-travelers on Earth. Not

392 simply because we depend on plants for the oxygen that we breathe, the food that we eat, and

393 even the gasoline that we use to drive our cars. Not simply because we depend on animals for the

394 high-energy protein that graces our tables, companionship by the hearth, and for decomposing

395 our carcasses when we die. But because the evolutionary play that causes some species to eat

396 others, that causes other species to help others, and that causes most species to be indifferent to

397 most others is the decisive expression of the sublime - the terrible uncertainty and ultimate

398 incomprehensibility of the world around us and a world that includes us. We can poke, prod, and

399 destroy what we do not understand, or we can reimagine it, revel in it, and celebrate it.

$400 \quad$ Landscape artists, landscape architects, and ecologists have joint responsibilities.

401 Landscape artists and landscape architects must illustrate and re-imagine what they see: in

402 painting, photography, video, sculpture, and in planned, designed, and engineered landscapes

403 themselves. They must re-express the sublime - not the terrifying disconnection between humans 
404 and "the environment" and the despair of the human condition - but the chaotic interplay of the

405 Earth and all its creatures, large and small, animals and plants, fungi and parasites. And

406 landscape artists must also re-connect with the broader society—like the Hudson River School

407 "rock stars", landscape artists must bring their postmodern visions to the world. Likewise,

408 ecologists and environmentalists need to give up the illusion of nature "out there," better off

409 without people, and balanced in perpetuity. Ecologists can work with the contextual framework

410 of postmodernism (e.g., Feyerabend 1987) and view landscapes through the eyes of artists who

411 envision the present, not mourn the past, and find new metaphors that capture and celebrate the

412 caprice, uncertainty, chaos and destruction of evolution. ${ }^{15}$ And in the end, we all need to shrug

413 off the embrace of the romantic landscape and reengage with the world. It's the only one we

414 have.

415

\section{ACKNOWLEDGMENTS}

417 This essay is a much-expanded version of a 2009 lecture delivered at Boston University's School 418 of Visual Arts, and the first part of the author's ongoing study of ecology and the challenge of 419 modernism. It was completed during a Scholar-in-Residence week at the H. J. Andrews 420 Experimental Forest Long Term Ecological Research (LTER) site in October 2010. Support was 421 provided by the LTER Reflections program, a partnership of the Andrews Forest LTER, the 422 USDA Forest Service Pacific Northwest Research Station, Oregon State University, and the US 423 National Science Foundation. Elizabeth Farnsworth, Robert Farnsworth, Robert Herbert, Debby

424 Kaspari, Kristina Stinson, four anonymous reviewers, and Dave Pitt, editor of Landscape

425 Journal, provided helpful critiques of early versions of the manuscript. 


\section{REFERENCES}

Andrews, Malcolm. 1999. Landscape and Western Art. Oxford, U.K.: Oxford University Press.

Bedell, Rebecca. 2001. The Anatomy of Nature: Geology and American Landscape Painting, 1825-1875. Princeton, NJ: Princeton University Press.

Bernal, John D. Art and the scientist. In Circle: International Survey of Constructive Art, eds. John Leslie Martin, Ben Nicholson, and Naum Gabo, 119-129. London, UK: Faber \& Faber.

Borlaug, Norman. 1972. Mankind and civilization at another crossroad: in balance with naturea biological myth. BioScience 22: 41-44.

Botkin, Daniel B. 2012. The Moon in the Nautilus Shell. Oxford, UK: Oxford University Press.

Bracken, Louise J., and John Wainwright. 2006. Geomorphological equilibrium: myth and metaphor?" Transactions of the Institute of British Geographers 31: 167-178.

Brown, Dona. 1995. Inventing New England: Regional Tourism in the Nineteenth Century. Washington, DC: Smithsonian Institution Press

Buijs, Arjen E., Bas J. M. Arts, Birgit H. M. Elands, and Jaap Lengkeek. 2011. Beyond environmental frames: the social representation and cultural resonance of nature in conflicts over a Dutch woodland. Geoforum 42: 329-341.

Cahoone, Lawrence E., editor. 2003. From Modernism to Postmodernism: An Anthology Expanded. Malden, MA: Blackwell Publishing Ltd.

Chapin, Terry, David Foster, Tim Kratz, and Fred Swanson. 2010. LTER engages Arts and Humanities. LTER Network News 23 (2): 2212. Online at: http://news.lternet.edu/Article2212.html.

Clements, Frederic E. 1936. Nature and structure of the climax. Journal of Ecology 24: 252-284. 
450 Colombaroli, Daniele, and Daniel G. Gavin. 2010. Highly Episodic fire and erosion regime over the past 2,000 y in the Siskiyou Mountains, Oregon. Proceedings of the National

Cook, Robert E. 2000. Do landscapes learn? Ecology’s “new paradigm” and design in landscape

Downing, Andrew J. 1842.Cottage Residences, or, a Series of Designs for Rural Cottages and

Downing, Andrew J. 1841. A Treatise on the Theory and Practice of Landscape Gardening, architecture. In Environmentalism in Landscape Architecture, ed. Michael Conan, 115132. Washington, DC: Dumbarton Oaks Research Library and Collection.

Cosgrove, Dennis E. 1998. Social Formation and Symbolic Landscape. Madison, WI: University of Wisconsin Press.

Cosgrove, Dennis E. 2008. Seminar discussion. In Landscape Theory, ed. Rachael Ziady Delue and James Elkins, 128. New York: Routledge.

Cronon, William. 1995. The trouble with wilderness: or, getting back to the wrong nature. In Uncommon Ground: Rethinking the Human Place in Nature, 69-90. New York, NY: W. W. Norton \& Co. Adapted to North America; With a View to the Improvement of Country Residences. New York, NY: Wiley \& Putnam.

472 Ellison, Aaron M. 2013. Stopping the hands of time. Ecology 94: 000-000. 
473 Ellison, Aaron M., Michael S. Bank, Barton D. Clinton, Elizabeth A. Colburn, Katherine Elliott, 474 Chelcy R. Ford, David R. Foster, Brian D. Kloeppel, Jennifer D. Knoepp, Gary M. Ecology and the Environment 9: 479-486.

480 Feyerabend, Paul. 1987. Farewell to Reason. London, UK: Verso.

481 Forbes, Stephen A. 1887. The lake as a microcosm. Bulletin of the Peoria Scientific Association 482

Heringman, Noah. 2004. Romantic Rocks, Aesthetic Geology. Ithaca, NY. Cornell University

Haeckel, Ernst. 1866. Generelle Morphologie der Organismen. Allgemeine Grundzüge der organischen Formen-Wissenschaft, mechanisch begründet durch die von Charles Darwin reformirte Descendenz-Theorie. Berlin: G. Reimer.

Harrison, Charles. 2003. Abstract art: reading Barnett Newman's Eve. In Frameworks for Modern Art, ed. Jason Gaiger, 105-151. London, UK: Yale University Press.

494 Hicks, Bob. 2010. Window on the West: One-painting exhibit, Thomas Moran's 'Shoshone 495 Falls,' opens at Portland Art Museum. The Oregonian, October 22, 2010. (available 
496

497

498

499

500

501

502

503

504

505

506

507

online at:

http://www.oregonlive.com/art/index.ssf/2010/10/shoshone_falls_at_the_portland.html).

Hill, Dawn, and Terry C. Daniel. 2011. Foundations for an ecological aesthetic: can information alter landscape preferences? Society and Natural Resources 21: 34-49.

Hood, Graham. 1969. Thomas Cole’s Lost Hagar. American Art Journal 1 (2): 41-52.

Jones, Clive G., John H. Lawton, and Moshe Shachak. 1994. Organisms as ecosystem engineers. Oikos 69: 373-386.

Jordan, William R., III, and George M. Lubick. 2011. Making Nature Whole: A History of Ecological Restoration. Washington, DC: Island Press.

Joselit, David. 2013. After Art. Princeton, NJ: Princeton University Press.

Kastner, Jeffrey, and Brian Wallis. 1998. Land and Environmental Art. London, UK: Phaidon Press Limited.

Kelsch, Paul. 2000. Constructions of American forest: four landscapes, four readings. In Environmentalism in Landscape Architecture, ed. Michael Conan, 163-186. Washington, DC: Dumbarton Oaks Research Library and Collection.

Kelsey, Robin. 2008. Seminar discussion. In Landscape Theory, ed. Rachael Ziady Delue and James Elkins, 128. New York: Routledge.

Kingsland, Sharon E. 2008. The Evolution of American Ecology, 1890-2000. Baltimore, MD: The Johns Hopkins University Press.

Kricher, John. 2009. The Balance of Nature: Ecology's Enduring Myth. Princeton, NJ: Princeton University Press.

Kroeber, Karl. 1975. Romantic Landscape Vision: Constable and Wordsworth. Madison, WI: University of Wisconsin Press. 
519 Lanchner, C. 2010. Fernand Léger. New York: The Museum of Modern Art, and Distributed Art $520 \quad$ Pulbishers, Inc.

521 Larson, Brendon. 2011. Metaphors for Environmental Sustainability: Redefining our 522 Relationship with Nature. New Haven, CT: Yale University Press.

523 Lovelock, James. E. 1965. A physical basis for life detection experiments. Nature. 207: 568-570.

524 Lovelock, James E., and Lynn Margulis. 1974. Homeostatic tendencies of the Earth's

525 atmosphere." Origins of Life 5: 93-103.

526 Macintosh, Robert P. 1985. The Background of Ecology: Concept and Theory. Cambridge, U.K.:

$527 \quad$ Cambridge University Press.

528 Mancini, JoAnne Marie. 2001. Pre-Modernism: Art-World Change and American Culture from

529 the Civil War to the Armory Show. Princeton, NJ: Princeton University Press.

530 Markonish, Denise. 2008. Manifest density to global warming: a pre-apocalyptic view of the $531 \quad$ landscape. In Badlands: New Horizons in Landscape (exhibition catalog), ed. Denise 532 Markonish, 18. North Adams, MA: Massachusetts Museum of Contemporary Art, and 533 Cambridge, MA: MIT Press.

534 Martínez-Frías, María Luisa. 2008. The balance of nature: reflections on the physics and 535 mathematics structure of the living world and the human genome. American Journal of

537 McHarg, Ian L. 1969. Design with Nature. Garden City, NY: Natural History Press.

538 Meyer, Elizabeth K. 2000. The post-Earth Day conundrum: translating environmental values into 539 landscape design. In Environmentalism in Landscape Architecture, ed. Michael Conan, 540 187-244. Washington, DC: Dumbarton Oaks Research Library and Collection. 
541 Nadenicek, Daniel Joseph and Catherine M. Hastings. 2000. Environmental rhetoric,

542 environmental sophism: the words and work of landscape architecture. In Environmentalism in Landscape Architecture, ed. Michael Conan, 133-161. Washington, DC: Dumbarton Oaks Research Library and Collection.

545 Nassauer, Joan I. 1995. Messy ecosystems, orderly frames. Landscape Journal 14 (2): 161-170.

546 Nicholls, Steve. 2009. Paradise Found: Nature in America at the Time of Discovery. Chicago, 547 IL: University of Chicago Press.

548 Nivala, John F. 1988. Our nature in balance: an essay on eighteenth-century landscape gardening 549 and twentieth-century lawyering. Journal of Legal Education 38: 305-314.

550 Odum, Eugene P. 1969. The strategy of ecosystem development. Science 164: 262-270.

551 OED. 2011. Oxford English Dictionary: The definitive record of the English language, $3^{\mathrm{rd}}$ 552 edition. Oxford: Oxford University Press.

553 Organ, John F. 2012. Celebrating 75 years: the evolution of a professional society. The Wildlife $554 \quad$ Professional 6(3): 24-31.

555 Perry, Gill. 2003. The expanding field: Ana Mendieta’s Silueta series. In Frameworks for 556 Modern Art, ed. Jason Gaiger, 153-205. London, UK: Yale University Press.

557 Poggi, Christine. 2008. Inventing Futurism: The Art and Politics of Artificial Optimism.

$558 \quad$ Princeton, NJ: Princeton University Press

559 Power, Mary E., and F. Stuart Chapin, III. 2010. Planetary stewardship in a changing world:

560 paths towards resilience and sustainability. Bulletin of the Ecological Society of America $56191: 143-175$. 
562 Roosevelt, Theodore. 1903. At Grand Canyon, Arizona, May 6, 1903. In Presidential Addresses and State Papers, February 19, 1902 to May 13, 1903. New York: The Review of Reviews Company.

Roth, Moira. 2004. An interview with Robert Smithson (1973). In Robert Smithson, ed. Eugenie Tsai, 80-95. Los Angeles, CA: The Museum of Contemporary Art.

Schuyler, David. 2012. Sanctified Landscape: Writers, Artists, and the Hudson River Valley, 1820-1909. Ithaca, NY: Cornell University Press.

Smith, Roger C. 1932. Upsetting the balance of nature, with special reference to Kansas and the Great Plains." Science 75: 649-654.

Spirn, Anne Whiston. 2008. “One with nature:” landscape, language, empathy, and imagination. In Landscape Theory, ed. Rachael Ziady Delue and James Elkins, 54. New York: Routledge.

Strong, Donald R. 2008. Ecologists and environmentalism. Frontiers in Ecology and the Environment 6: 347.

Struck, Doug. 2010. New England's stately trees give way as the region warms. The Daily Climate, 22 June 2010 (http://wwwp.dailyclimate.org/tdc-newsroom/2010/06/trees).

Swanson, Frederick J., and Douglas N. Swanston. 1977. Complex mass-movement terrains in the western Cascade Range, Oregon. Reviews in Engineering Geology 3: 113-124.

Tepley, Alan J. 2010. Age Structure, Developmental Pathways, and Fire Regime Characterization of Douglas fir/Western Hemlock Forests in the Central Western Cascades of Oregon. Ph.D. Dissertation, Oregon State University, Corvallis, Oregon. 
583 Tsai, Eugenie. 2004. Robert Smithson: Plotting a line from Passaic, New Jersey to Amarillo,

584 Texas. In Robert Smithson, ed. Eugenie Tsai, 10-31. Los Angeles, CA: The Museum of Contemporary Art.

586

587

van Marwijk, Ramona B. M., Birgit H. M. Elands, Jarl K. Kampen, Sander Terlouw, David G. Pitt, and Paul Opdam. 2012. Public perceptions of the attractiveness of restored nature. Restoration Ecology 20: 773-780.

van Valen, Leigh. 1973. A new evolutionary law. Evolutionary Theory 1: 1-30

Volk, Gregory. 2008. Transparent eyeball. In Badlands: New Horizons in Landscape (exhibition catalog), ed. Denise Markonish, 177. North Adams, MA: Massachusetts Museum of Contemporary Art, and Cambridge, MA: MIT Press.

Wallace, Bruce. 1873. The Hudson River by Daylight. New York, NY: Gaylord Watson.

Whelan, Tensie. 2008. People and the plane. In Badlands: New Horizons in Landscape (exhibition catalog), ed. Denise Markonish, 121. North Adams, MA: Massachusetts Museum of Contemporary Art, and Cambridge, MA: MIT Press.

Wood, Paul. 2003. Art of the twentieth century. In Frameworks for Modern Art, ed. Jason Gaiger, 5-55. London, UK: Yale University Press.

Wood, Paul. 2004. The idea of an abstract art. In Art of the Avant-Gardes, eds. Steve Edwards and Paul Wood, 229-271. London, UK: Yale University Press.

Wu, Jianguo, and Orie Loucks. 1995. From balance of nature to hierarchical patch dynamics: a paradigm shift in ecology. Quarterly Review of Biology 70: 439-466.

Zimmerman, Corinne, and Kim Cuddington. 2007. Ambiguous, circular and polysemous: students' definitions of the "balance of nature" metaphor. Public Understanding of Science 16: 393-406. 
607

608

$609 \times 120$ in (Collection of the artist; reproduced with permission of the artist).

FIGURE LEGENDS

610

611 Figure 2. Caspar David Friedrich, The Monk by the Sea, 1809, oil on canvas, $110 \times 171.5 \mathrm{~cm}$.

612 (Nationalgalerie, Staatliche Museen zu Berlin. Photo credit @ B Bildarchiv Preussicher

613 Kluturbesitz / Art Resource, NY).

614

615 Figure 3. Joseph Mallord William Turner, Snow Storm - Steam-Boat off a Harbour's Mouth, 6161842 , oil on canvas, $914 \times 1219 \mathrm{~mm}$ painting, $1233 \times 1535 \times 145 \mathrm{~mm}$ frame. (Tate Gallery, 617 London (Accession number N00530; Digital image @ T Tate, London, 2009)).

618

619 Figure 4. Piet Mondrian, Broadway Boogie Woogie, 1942-43, oil on canvas, $50 \times 50$ in.

620 (Metropolitan Museum of Art, New York. Digital image (C) The Museum of Modern Art /

621 Licensed by SCALA / Art Resource, NY).

622

623 Figure 5. Fernand Léger, La Ville - Le Viaduc, 1959, lithograph. (Collection of the author).

625 Figure 6. Irregular peaks of establishment of Douglas-fir seedlings in Pacific Northwest old626 growth forests. (From Tepley (2010), and reproduced with permission of the author).

628 Figure 7. Split Tree, original digital image by Elizabeth Farnsworth, $8.3 \times 32.6$ in. (@) Elizabeth 629 Farnsworth. Collection of the author, and reproduced with permission of the artist). 
630 Figure 8. Elizabeth Farnsworth, Légerian Forest, pen \& ink on paper, $11.5 \times 11.5$ in. (Collection 631 of the author, and reproduced with permission of the artist).

632 


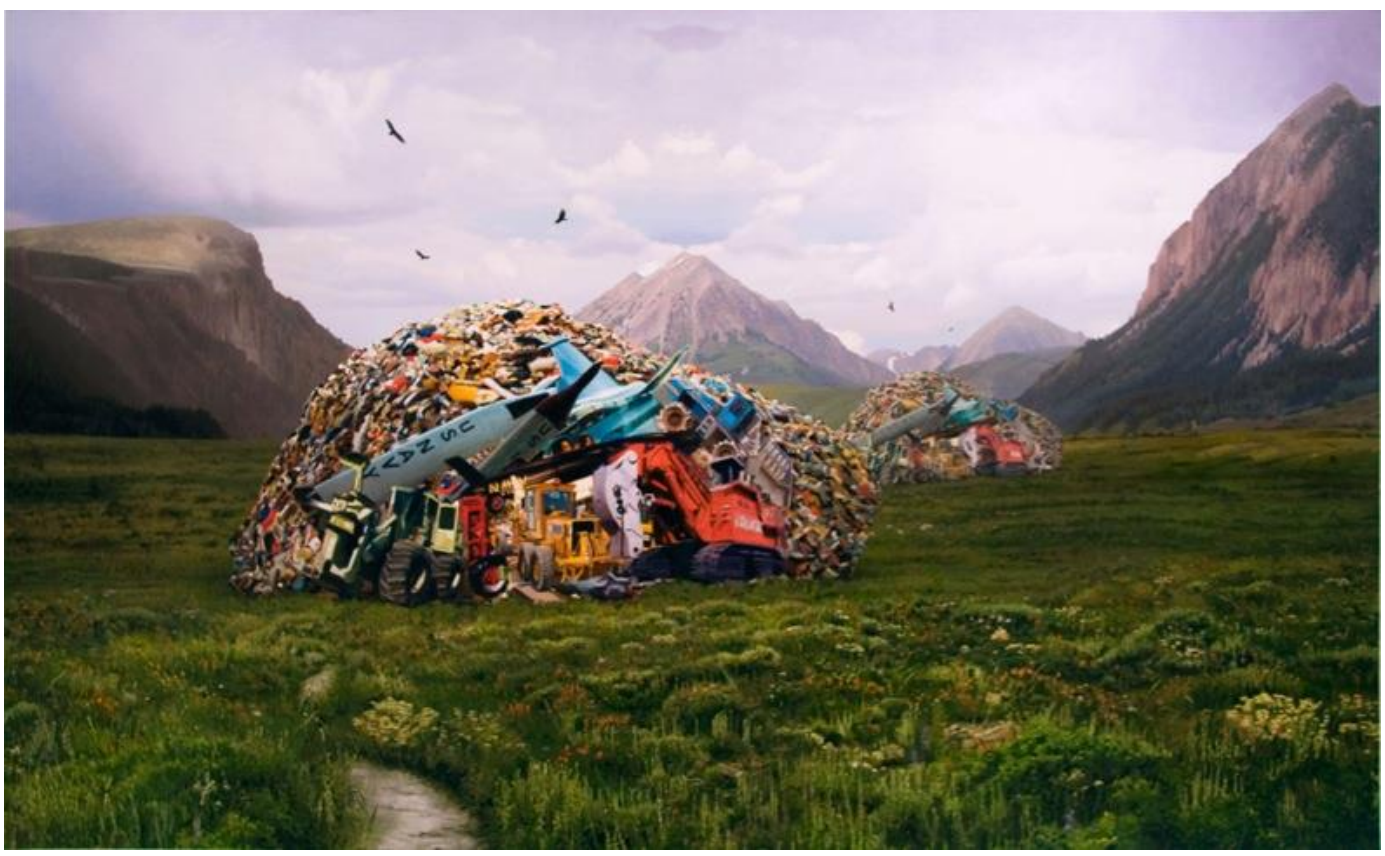

634

Figure 1

635

636

637

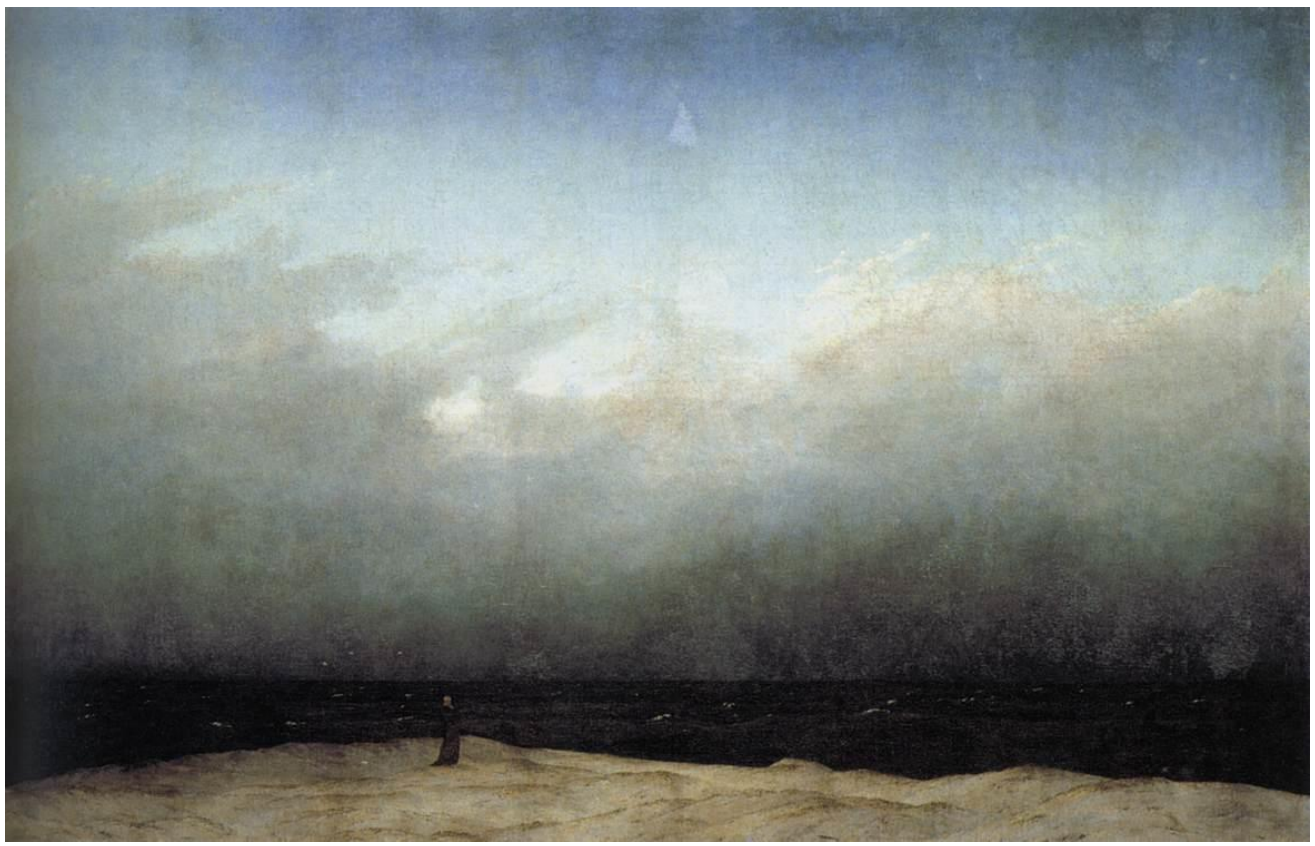

Figure 2

638 


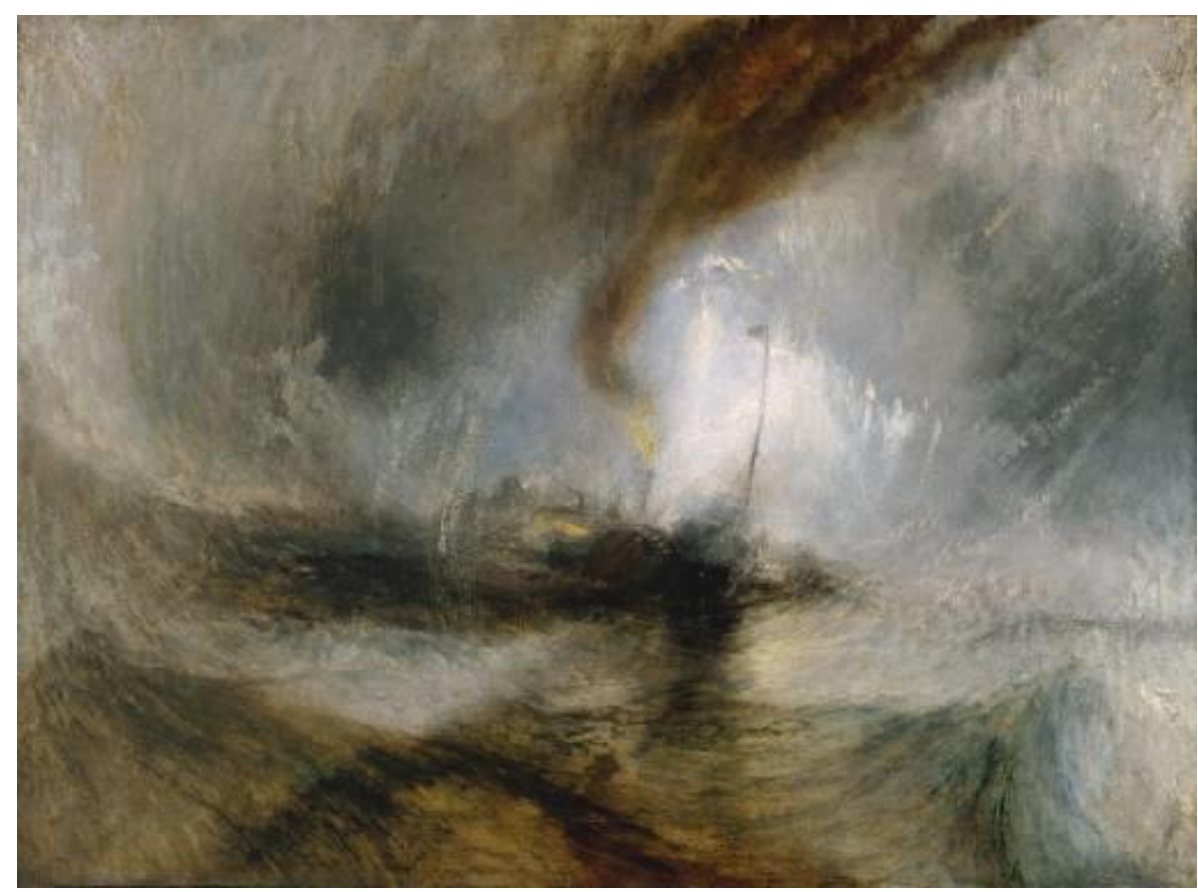

Figure 3

641

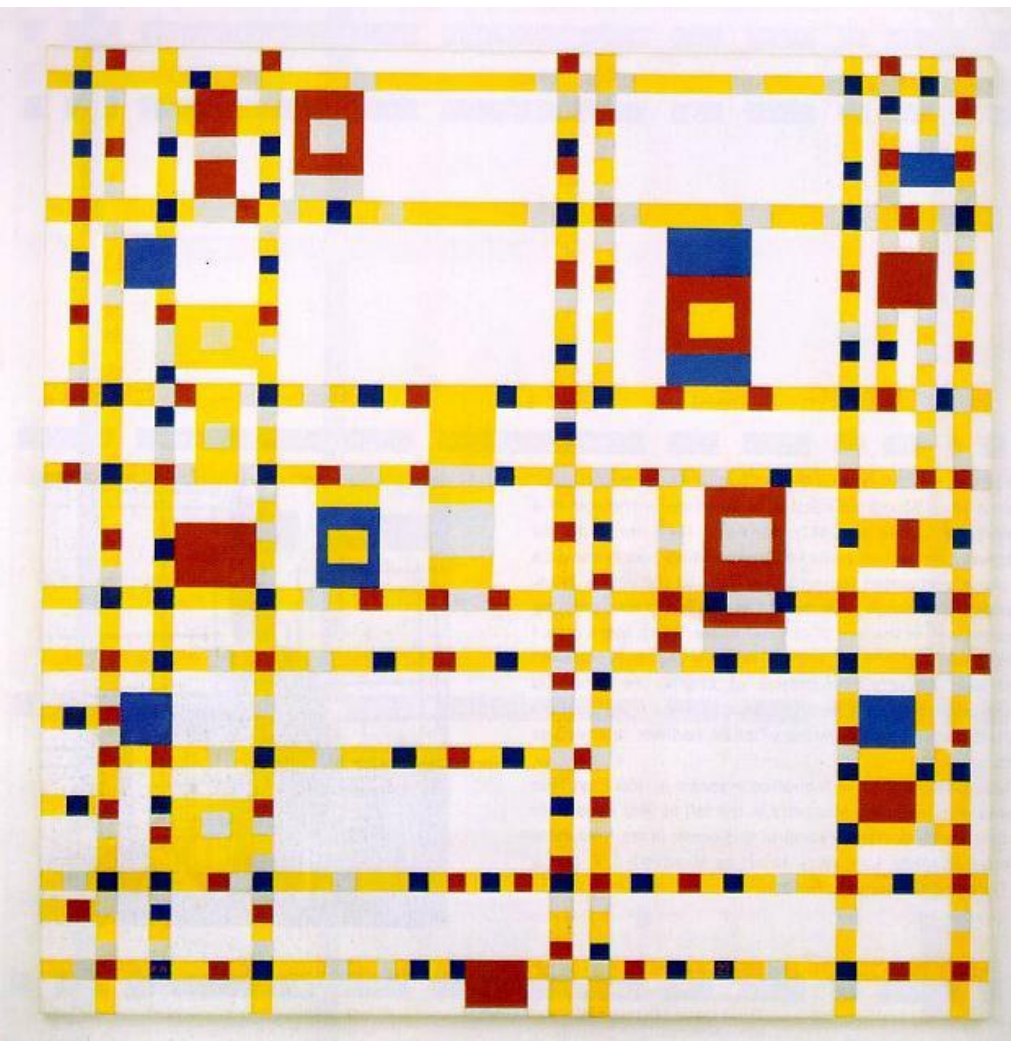

Figure 4 


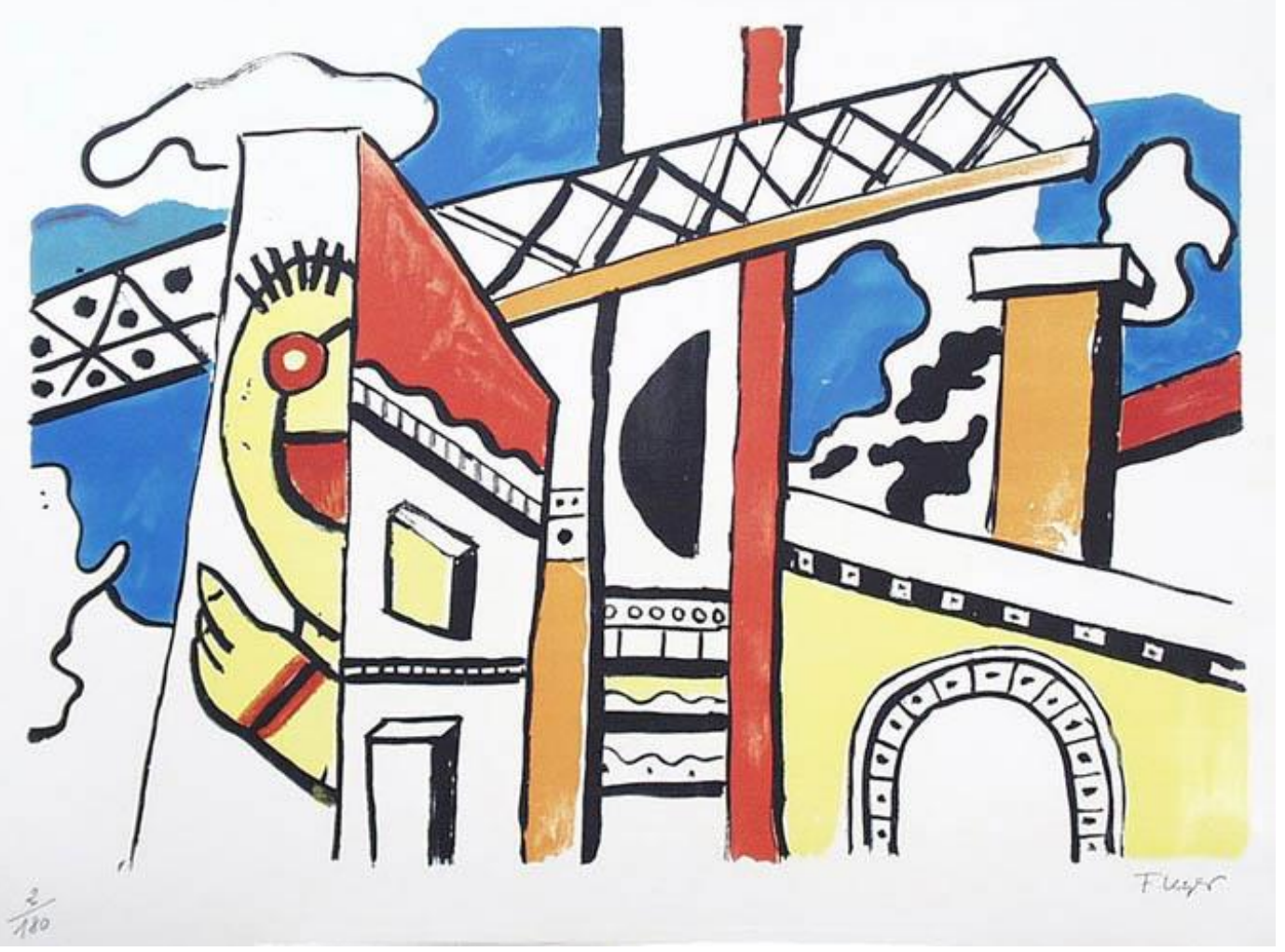

645

Figure 5

646

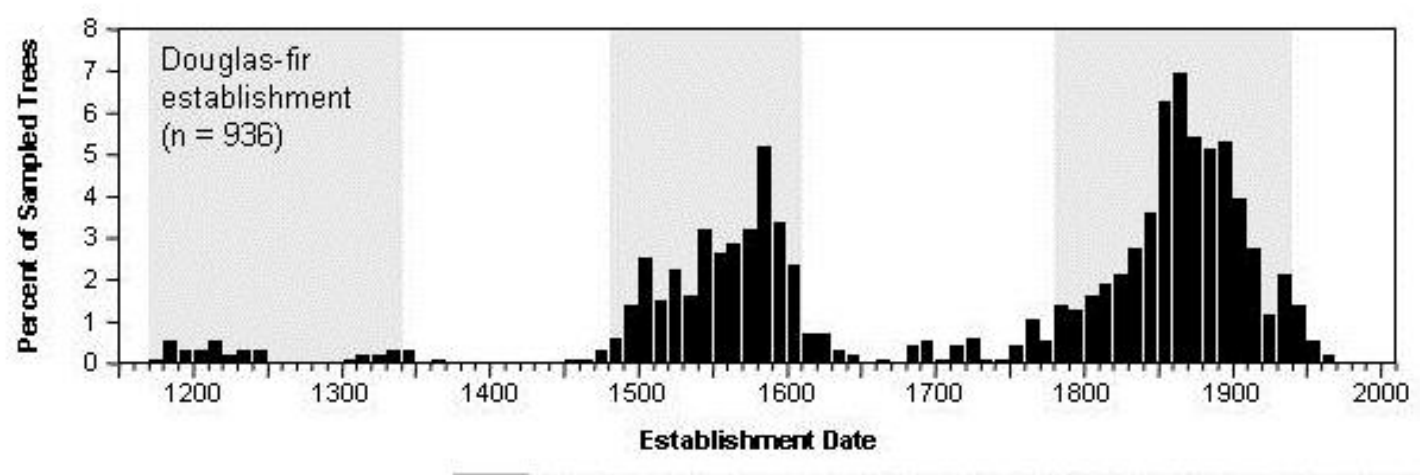

647

648

Figure 6 
650

651

652

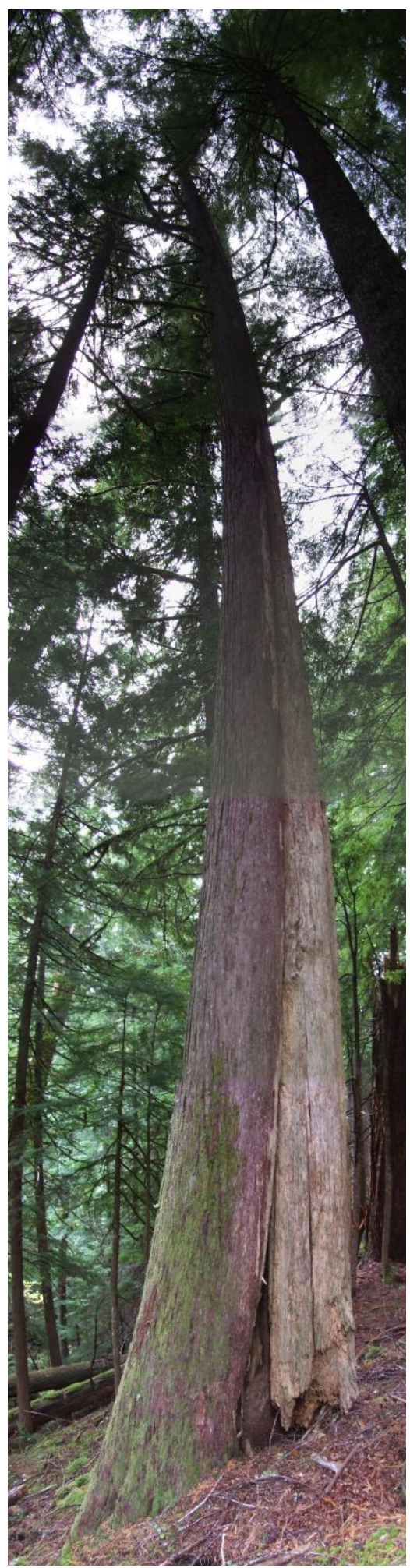

Figure 7 


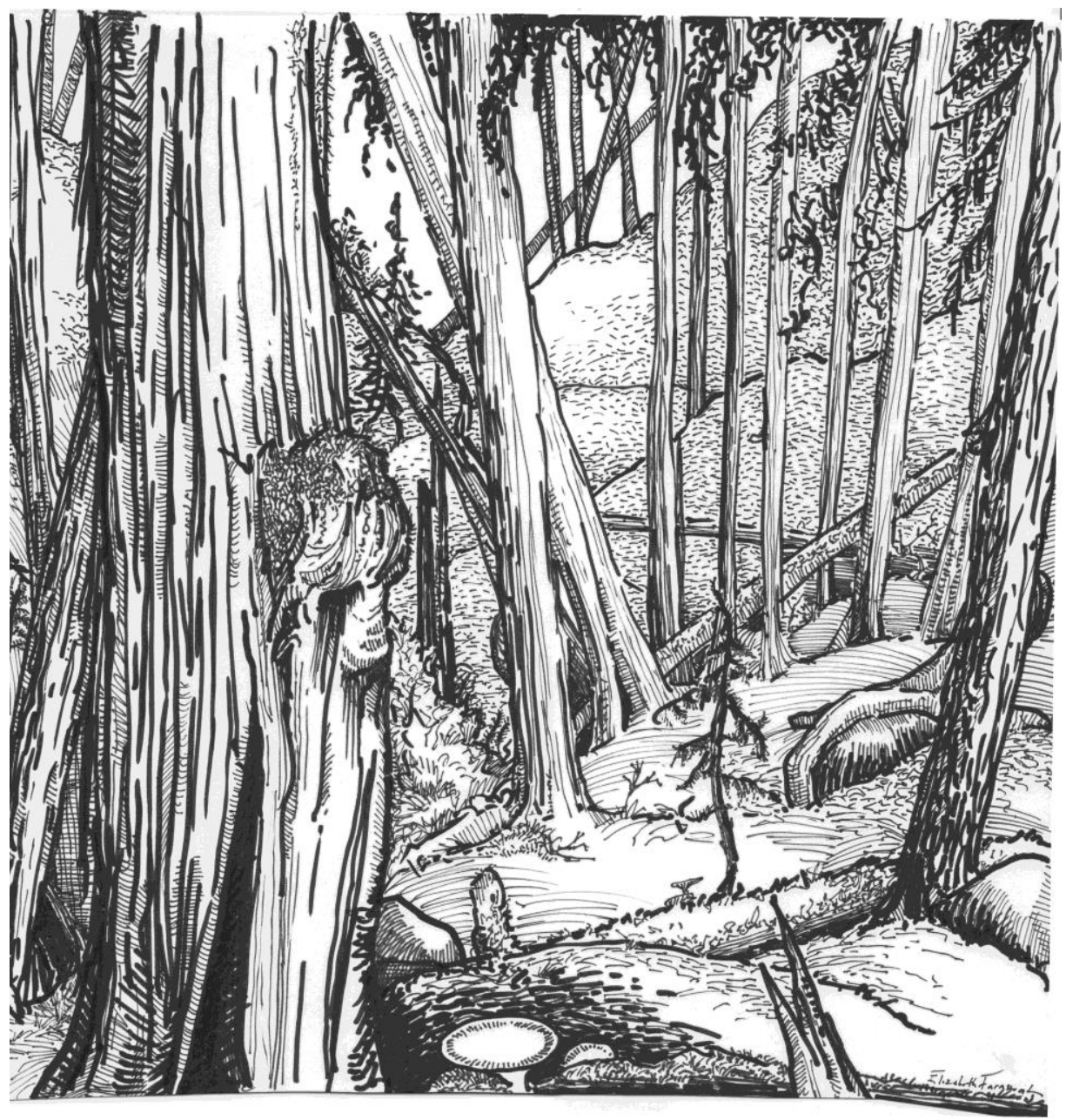

Figure 8

656 
658 AUTHOR Aaron M. Ellison studies how ecological communities assemble, disassemble, and 659 reassemble in disturbed landscapes. He has taught at Cornell, Swarthmore, Mount Holyoke, and 660 the University of Miami. He is currently Senior Research Fellow in Ecology at the Harvard

661 Forest, Research Professor of Biology at the University of Massachusetts-Amherst, and Editor662 in-Chief of Ecological Monographs.

663 


\section{NOTES}

${ }^{1}$ I use "ecology" here to mean ecology as a science - the study of the distribution and abundance of organisms and their relationships to, and interactions with, their environment.

${ }^{2}$ Any one of these parts alone could be expanded into a full-length essay or book. This essay is meant more to stimulate debate, discussion, and engagement than to be fully comprehensive.

${ }^{3}$ I use four key terms-Modernism, Postmodernism, sublime, and picturesque — as follows. Modernism emphasizes the independence of a work of art from anything outside of art (e.g., in contrast to classical landscape paintings); its form; and its aesthetic effects (Wood 2003, 22). Modernism also refers to artistic and broader cultural response to modernity - progress seen as increasing rates of technological innovation and urbanization in an anonymized, mass society (Poggi 2008). Postmodernism "quotes or otherwise comments on, ironizes, or takes a critical distance from 'modernist' abstraction" (Wood 2004, 229); explicitly incorporates the perspective of the artist (creator) along with his/her cultural background and perceptions (Meyer 2000, 229); emphasizes relativism and context, and de-emphasizes progress (e.g, Feyerabend 1987, Cahoone 2003). In $19^{\text {th }}$-century landscape gardening and early landscape architecture, three types of views were often considered: the beautiful, the picturesque, and the sublime. Picturesque initially was characterized by forms and arrangements that conveyed a sense of the raw power of the natural world and the caprices of wild nature; it was contrasted with beautiful, which was more graceful, soft, and luxuriant (Downing 1841, quoted in Schuyler 2012, 72). In contrast, the late $19^{\text {th }}$-century writer Bruce Wallace characterized the rolling hills north of Newburgh in the Hudson Highlands as 
picturesque and the Catskill Mountains as beautiful (Wallace 1873, 57 and 67; quoted in Schuyler 2012, 20). Wallace's use of picturesque and beautiful inverted Downing's, but is more in line with that used by modernist landscape artists and architects (and in this essay) (cf. Meyer 2000, 211). The sublime conveys the "frisson of fear that comes from confronting something more powerful than oneself" (Beddell 2001, 105); sublimity creates sensations of wonder, awe, or terror (Harrison 2003, 109).

${ }^{4}$ By way of example, Thomas Kinkade's painting Mountain Majesty (Beginning of a Perfect Day III) hangs in the center of the cafeteria and conference center at the H. J. Andrews Long Term Ecological Research (LTER) site in Blue River, Oregon. Scientists at the Andrews LTER study how forest management, natural disturbances, and climatic change affect old-growth forests. Ironically, this painting, whose intent is to "find the truth of the Psalm confirmed by the radiance of sunrise, by a shimmering memory of a rainbow... especially by a towering snow-capped peak, like the one that stands as a silent sentinel in Mountain Majesty" (http://www.thomaskinkade.com/magi/servlet/com.asucon.ebiz.catalog.web.tk.CatalogSe rvlet?catalogAction=Product\&productId=1497\&menuNdx=0), is juxtaposed with a timeline of research at the Andrews that highlights the dynamic environment and 50 years of constantly changing scientific paradigms. Researchers at the Andrews LTER recognized the irony, but only when the painting was actually pointed out to them. Previously, it had been only background eye-candy, representing the implicit yet contested assumptions of fundamental ecological research described in this essay. Botkin (2012, xii) encapsulates this irony with respect to management of rare species and natural resources: "[i]f you ask ecologists whether nature is constant, they will always say 'No, 
of course not.' But if you ask them to write down a policy for biological conservation or any other kind of environmental management, they will almost always write down a steady-state [i.e., 'nature is stable'] solution."

${ }^{5}$ Two recent examples include a one-painting exhibition of Thomas Moran's massive Shoshone Falls on the Snake River (1900), which took several years to plan and opened with great fanfare at the Portland Art Museum in October 2010, and the 2008-2009 Badlands: New Horizons in Landscape exhibition at the Massachusetts Museum of Contemporary Art.

${ }^{6}$ By way of example, one need only consider the contemporary painter Thomas Kinkade (b. 1958), self-described as "America's most collected living artist" (http://www.thomaskinkade.com), whose franchised galleries can be found in every state in the U.S.A., as well as in Canada, Ireland, Malaysia, Mexico, Russia, and the United Kingdom.

${ }^{7}$ Downing's designs were designed to be affordable, widely reproduced, and easily maintained (Schuyler 2012, 89). His Cottage Residences... (1842) and The Architecture of Country Houses (1861) remain in print to this day. In contrast, designs inspired by McHarg's sophisticated environmental planning were expensive, rarely implemented, and required much maintenance. For example, Spirn $(2000,111)$ describes McHarg's plan for Pardisan — an environmental park planned for outside Tehran, Iran—as ecologically and socially perverse, requiring (in a desert environment) constant irrigation and airconditioning.

${ }^{8}$ Environmental artists of the 1960s and 1970s (including Smithson) challenged a static or binary conception of nature. Smithson and those who followed him abandoned to some extent the Modernist emphasis on color, form, and materials in favor of a creative engagement 
with a temporally varying environment, e.g., Smithson’s focus on “entropy” (Perry 2003, 188; Tsai 2005, 21). Without repeated viewing, however, it is difficult to see the explicit evolution of Earth art installations (Perry 2003, 188). Ironically, Smithson himself stated that he was not interested in works without substantial permanence: "So I'm interested in something substantial enough that's permeate-perhaps permeate is a better word than permanent - in other words, something that can be permeated with change and different conditions" (in Roth 2005, 92). Meyer (2000, 197-198) points out that many landscape architects found in works by Smithson and Robert Irwin a (postmodern) alternative to the (by inference, modernist) abstraction of ecological analysis, instead focusing on sitespecific phenomena and processes that in turn would illuminate their larger-scale, longerterm causes. Ecologists work in similar ways, abstracting general patterns from specific instances. In both cases, the types of specific instances chosen, and the general patterns inferred, are conditioned not only by sites or exemplars but also by often unacknowledged assumptions (such as nature in balance).

${ }^{9}$ Paul Jacobsen, Statement, http://www.pauljacobsen.info/iWeb/Site/Statement.html.

${ }^{10}$ This type of statement is one of the most common responses to the critique that ecologists persist in viewing nature as being in balance. One reviewer of this essay wrote that "the dynamics and flow among various successional and developmental stages in response to windstorms and fires is well known to ecologists." Quite so, but our language betrays us-we call these events "disturbances."

${ }^{11}$ The balance of nature metaphor is so deeply embedded that it is assumed, not discussed in Larson's (2011) monograph, Metaphors for Environmental Sustainability. 
${ }^{12}$ This quotation is from the description of the painting on the web site of the Metropolitan Museum of Art: http://www.moma.org/colection/browse_results.php?object_id`78682).

${ }^{13}$ Although my surveys of artists and ecologists take place at the beginning of seminars I give on this topic and are informal, unstructured, and uncontrolled, the results are qualitatively indistinguishable from controlled studies subject to statistical analysis (e.g., Hill and Daniel 2008, van Marwijk et al. 2012). Such results have been used constructively to build consensus among stakeholders with very different views of picturesque landscapes for ecological restoration projects a.k.a. constructed landscapes (Buijs et al. 2011).

${ }^{14}$ With unintended ironically, Jordan and Lubick (2011) assert that successful ecocentric restoration is impossible without the disconnection between people and "nature." See Ellison (2013) for further discussion.

${ }^{15}$ A promising step in this direction is the continued support by the U.S. National Science foundation for the LTER-Arts program (LTEArts), which hosts artists at LTER sites throughout North America to re-interpret landscapes and ecology and collaborate with ecologists (Chapin et al. 2010; website at: http://www.ecologicalreflections.com/). 